\title{
UJI AKTIVITAS ANTIBAKTERI EKSTRAK METANOL MIKROALGA Chlorella sp. PADA FASE STASIONER HASIL KULTIVASI DALAM MEDIUM EKSTRAK TAUGE (MET)
}

\author{
Umi Khamidah $^{1}$, A. Ghanaim Fasya ${ }^{1}$, Romaidi ${ }^{2}$. \\ (1) Jurusan Kimia, Fakultas Sains dan Teknologi, UIN Maulana Malik Ibrahim Malang \\ (2) Jurusan Biologi, Fakultas Sains dan Teknologi, UIN Maulana Malik Ibrahim Malang
}

\begin{abstract}
Chlorella $s p$. is one of microalgae Chlorophyta that containing kinds of important compound such as flavonoid, tanin, phenolic compound, terpenoid, chlorophyll and karotenoid. The purpose of this research are to know antibacterial activity from methanol extract of microalgae Chlorella $s p$. at stationary phase and to know contains of active compound group in extract of microalgae Chlorella sp. Chlorella sp. was cultivated in Tauge Extract Medium (TEM) $4 \%$ and harvesting of stationary phase. Extraction microalgae Chlorella $s p$. was performed by maceration with methanol solvent. Methanol extract from stationary phase were tested antibacterial activity with concentration variation $5 \%, 10 \%, 15 \%, 20 \%$, and $25 \%$ used diffusion method toward E. coli and S. aureus bacterium. Identification of active compound was estimated by reagent tested on qualitative scale include alkaloid, falvonoid, steroid, triterpenoid, and tanin. The result showed that methanol extract of Chlorella sp. in stationary phase in concentration \%, $10 \%, 15 \%, 20 \%$, and $25 \%$ with inhibition zone as follows 1,0 mm, 3,7 mm, 6,9 mm, 16,5 mm and 12,1 mm toward E. coli bacterium and 2,2 mm, 4,9 mm, 3,0 $\mathrm{mm}, 7,4 \mathrm{~mm}$, and $13,1 \mathrm{~mm}$ toward $S$. aureus bacterium. The results of the identification of the compound methanol extract of microalgae Chlorella sp.contains a steroid and tanin compound class.
\end{abstract}

Keywords : Chlorella sp. Antibacterial, Tauge Extract Medium.

\begin{abstract}
ABSTRAK
Chlorella sp. merupakan salah satu jenis mikroalga Chlorophyta yang mengandung berbagai senyawa penting yang seperti flavonoid, tanin, senyawa fenolik, terpenoid, klorofil dan karotenoid. Penelitian ini bertujuan untuk mengetahui aktivitas antibakteri ekstrak metanol mikroalga Chlorella sp. fase stasioner serta untuk mengetahui kandungan golongan senyawa aktif dalam ekstrak mikroalga Chlorella $s p$. Chlorella $s p$. dikultivasi dalam Medium Ekstrak Tauge (MET) $4 \%$. Pemanenan Chlorella sp. dilakukan pada fase stasioner. Ekstraksi mikroalga Chlorella sp. dilakukan dengan metode maserasi menggunakan pelarut metanol. Ekstrak metanol dari fase stasioner tersebut diuji aktivitas antibakteri dengan variasi konsentrasi $5 \%, 10 \%, 15 \%, 20 \%$, dan $25 \%$ menggunakan metode difusi cakram terhadap bakteri E. coli dan S. aureus. Identifikasi golongan senyawa aktif dilakukan dengan menggunakan uji reagen secara kualitatif yang meliputi alkaloid, flavonoid, steroid, triterpenoid, dan tanin. Hasil penelitian menunjukkan bahwa ekstrak metanol Chlorella sp. fase stasioner pada konsentrasi $5 \%, 10 \%, 15 \%, 20 \%$, dan $25 \%$ menghasilkan zona hambat berturut-turut 1,0 mm, 3,7 mm, $6,9 \mathrm{~mm}, 16,5 \mathrm{~mm}$ dan $12,1 \mathrm{~mm}$ terhadap bakteri $E$. coli dan 2,2 mm, 4,9 mm, 3,0 mm, 7,4 mm dan 13,1 mm terhadap bakteri $S$. aureus. Hasil identifikasi golongan senyawa aktif menunjukkan bahwa ekstrak metanol Chlorella sp. mengandung golongan senyawa steroid dan tanin.
\end{abstract}

Kata kunci : Chlorella sp., Antibakteri, Medium Ekstrak Tauge

\section{PENDAhUluAN}

Mikroalga adalah mikroorganisme fotosintetik dengan morfologi sel yang bervariasi, baik uniseluler maupun multiseluler (membentuk koloni kecil) (Becker, 1994). Mikroalga memiliki keunggulan dibandingkan dengan makroalga dan tumbuhan tingkat tinggi. Keunggulannya antara lain hidupnya tidak tergantung musim, tidak memerlukan tempat yang luas, dan tidak memerlukan waktu yang lama untuk memanennya (Borowitzka, 1988).

Mikroalga menghasilkan beberapa vitamin penting, seperti vitamin $A, B_{1}, B_{2}$, $\mathrm{B}_{6}, \mathrm{~B}_{12}, \mathrm{C}, \mathrm{E}$, nikotinamida, biotin, asam folat, dan asam pantotenat. Pigmen yang dihasilkan meliputi klorofil (0,5 sampai $1 \%$ 
dari berat kering), karotenoid (0,1 sampai $14 \%$ dari berat kering), dan fikobiliprotein (Becker, 1994).

Salah satu jenis mikroalga dari golongan Chlrophyta adalah Chlorella sp. Chlorella sp. memiliki potensi sebagai pakan alami, pakan ternak, suplemen, penghasil komponen bioaktif bahan farmasi dan kedokteran. Dalam bidang pangan dapat dikembangkan untuk pangan sehat sebagai sumber protein, vitamin, dan mineral, dalam bidang kedokteran dapat bermanfaat untuk mencegah penyakit kanker, menurunkan tekanan darah tinggi, menurunkan kadar kolesterol darah dan sebagainya (Steenblock, 1996). Komposisi kimia Chlorella sp. terdapat pada Tabel 1.

Tabel 1. Komposisi kimia Chlorella sp.

\begin{tabular}{|c|c|}
\hline $\begin{array}{l}\text { Komposisi } \\
\text { Chlorella sp. }\end{array}$ & Kimia (\%) \\
\hline Karbohidrat & 20,6 \\
\hline Protein & 30,9 \\
\hline Lipid & 20,1 \\
\hline Lain-lain & 28,4 \\
\hline
\end{tabular}

Sumber : Ben-Amotz, et al. (1987).

Beberapa penelitian melaporkan bahwa Chlorella sp. merupakan salah satu mikroalga yang mempunyai bioaktivitas sebagai antikanker. Sriwardani (2000) melaporkan bahwa ekstrak kloroform mikroalga Chlorella sp. mampu menghambat pertumbuhan bakteri E. coli sebesar 46,2 \%. Abedin dan Taha (2008) juga melaporkan bahwa ekstrak metanol Chlorella pyrenoidosa menghasilkan diameter zona hambat sebesar $10 \mathrm{~mm}$ terhadap bakteri $E$. coli dan $S$. aureus, sedangkan ekstrak etanol menghasilkan diameter zona hambat sebesar $25 \mathrm{~mm}$ terhadap bakteri $E$. coli dan tidak menghasilkan zona hambat terhadap $S$. aureus.

Yudha (2008) melaporkan bahwa ekstrak n-heksana dan ekstrak etil asetat mikroalga Dulaniella sp. pada fase log terhadap bakteri uji Staphylococcus aureus, Bacillus cereus, Eschericia coli, dan Vibrio harveyi menghasilkan diameter zona hambat berturut-turut sebesar 3, 4, 3, $5 \mathrm{~mm}$, serta 2, 2, 2, $3 \mathrm{~mm}$, sedangkan ekstrak nheksana dan ekstrak etil asetat mikroalga Dulaniella $s p$. pada fase stasioner terhadap bakteri uji yang sama berturut-turut nilainya adalah 2, 2, 1, $4 \mathrm{~mm}$, serta 2, 3, 2, $4 \mathrm{~mm}$.

Komponen bioaktif dari mikroalga Chlorella sp. yang bisa menghasilkan efek farmakologis didapatkan dari biomassa Chlorella sp. Biomassa Chlorella sp. merupakan akumulasi dari sel Chlorella $s p$. hasil kultivasi dalam medium kultur. Untuk menghasilkan pertumbuhan mikroalga yang baik tentu diperlukan kondisi lingkungan dengan nutrien yang sesuai.Faktor-faktor yang mempengaruhi keberhasilan kultivasi Chlorella sp. adalah kualitas air yang meliputi suhu, salinitas, kekuatan cahaya, dan pH (Rostini, 2007).

Salah satu medium kultur yang bisa digunakan untuk medium kultivasi Chlorella sp. adalah Medium Ekstrak Tauge (MET). Medium Ekstrak Tauge (MET) merupakan medium kultur alami yang mengandung komponen-komponen yang dibutuhkan untuk pertumbuhan mikroalga Chlorella $s p$. seperti nitrogen dan fosfor. Penggunaan medium ekstrak tauge menghasilkan pertumbuhan mikroalga yang sangat pesat dibandingkan dengan medium lainnya yaitu Medium Air Laut (MAL) dan Medium Guillard (MG) (Wulandari, et al., 2010). Medium Ekstrak Tauge $4 \%$ merupakan medium yang cocok untuk kultivasi mikroalga (Prihantini, 2007).

Penelitian ini bertujuan untuk mengetahui aktivitas antibakteri ekstrak mikroalga Chlorella sp. pada fase stasioner yang dikultivasi dalam Medium Ekstrak Tauge (MET) dan golongan senyawa aktif yang terkandung di dalamnya.

\section{METODE PENELITIAN}

Penelitian ini dilaksanakan di Laboratorium Kimia Organik, Bioteknologi Jurusan Kimia dan Laboratorium Ekologi Jurusan Biologi Fakultas Sains dan 
Teknologi UIN Maulana Malik Ibrahim Malang pada bulan Maret - Mei 2013.

\section{Bahan dan Alat}

Bahan yang digunakan adalah isolat Chlorella sp. dari Laboratorium Ekologi UIN Maulana Malik Ibrahim Malang. Medium kultur menggunakan bahan tauge kacang hijau. Bakteri uji yang digunakan adalah Escherichia coli dan Staphylococcus aureus.

Bahan-bahan kimia yang digunakan adalah metanol p.a, media Nutrient Agar (NA), media Nutrient Broth (NB), penisilin dan streptomisin, asam asetat anhidrat, kloroform, $\mathrm{H}_{2} \mathrm{SO}_{4}$ pekat, $\mathrm{HCl} 2 \%, \mathrm{HCl}$ pekat, reagen Dragendroff, reagen Mayer, reagen Wagner, larutan gelatin, $\mathrm{FeCl}_{3} 1 \%$, metanol $50 \%$, logam $\mathrm{Mg}$, dan akuades.

\section{Cara Kerja}

Pembuatan Medium Ekstrak Tauge (MET) $4 \%$

Pembuatan medium ekstrak tauge diawali dengan pembuatan larutan stok MET yaitu 100 gram tauge direbus dalam $500 \mathrm{~mL}$ akuades yang mendidih selama 1 jam. Medium ekstrak tauge dibuat dengan cara melarutkan ekstrak tauge ke dalam akuades hingga diperoleh konsentrasi $4 \%$ (v/v) (Prihantini, et al., 2005).

\section{Kultivasi Chlorella sp. dalam MET}

Sebanyak $10 \mathrm{ml}$ isolat Chlorella $\mathrm{sp}$. diinokulasikan ke dalam masing-masing 60 $\mathrm{ml}$ media ekstrak tauge dalam erlenmeyer $1000 \mathrm{~mL}$ yang ditempatkan pada ruang dengan suhu $25-27{ }^{\circ} \mathrm{C}$ dan ditempatkan pada rak dengan pencahayaan menggunakan lampu TL 36 watt (intensitas cahaya 1000 - 4000 lux) dengan fotoperiodisitas 14 jam terang dan 10 jam gelap (Prihantini, et al., 2005).

\section{Pemanenan Biomassa Chlorella sp.}

Pemanenan biomassa Chlorella sp. dilakukan pada fase stasioner (hari ke-10). Pemanenan dilakukan dengan cara media kultur Chlorella sp. disentrifugasi selama 15 menit dengan kecepatan $3000 \mathrm{rpm}$.
Biomassa Chlorella sp. dipisahkan dari cairannya kemudian dilakukan penimbangan. Hasil penimbangan dicatat sebagai berat basah.

\section{Preparasi Sampel Biomassa Chlorella sp.} Sampel biomassa Chlorella sp. dari tiap-tiap fase pertumbuhan yang masih basah diletakkan di wadah terbuka yang bentuknya agak datar kemudian dikering anginkan pada suhu ruang $\left(25-30{ }^{\circ} \mathrm{C}\right)$ menggunakan kipas angin selama \pm 12 jam. Selanjutnya biomassa yang sudah dikering anginkan tersebut ditimbang.

\section{Ekstraksi Biomassa Chlorella sp.}

Biomassa Chlorella sp. dari fase stasioner yang sudah kering dimaserasi menggunakan pelarut metanol selama 24 jam dengan perbandingan sampel terhadap pelarut $1: 5(\mathrm{w} / \mathrm{v})$ dengan bantuan shaker \pm 5 jam, kemudian disaring. Residu dimaserasi 2 kali lagi masing-masing selama 24 jam hingga filtrat yang diperoleh bening, kemudian disaring. Filtrat yang diperoleh dikumpulkan dan dirotary evaporator hingga diperoleh ekstrak pekat.

\section{Uji Aktivitas Antibakteri Ekstrak Metanol Mikroalga Chlorella sp. terhadap E. Coli dan S. aureus}

\section{Pembuatan Media Agar}

Sebanyak 2,3 gr Nutrient Agar (NA) dilarutkan dalam $100 \mathrm{~mL}$ akuades dalam beaker glass dan dimasukkan dalam erlenmeyer dan ditutup kapas. Media cair (Nutrient Broth) dibuat dengan cara sebanyak 0,9 gr Nutrient Broth (NB) dilarutkan dalam $100 \mathrm{~mL}$ akuades, kemudian dimasukkan dalam erlenmeyer dan ditutup dengan kapas. Suspensi media agar tersebut dipanaskan hingga mendidih lalu dimasukkan ke dalam tabung reaksi. Selanjutnya disterilkan dalam autoklaf selama 15 menit pada suhu $121{ }^{\circ} \mathrm{C}$ dan tekanan 15 psi (per square inchi) (Volk dan Wheeler, 1993). 


\section{Peremajaan Bakteri}

Biakan murni S. aureus dan E. coli digoreskan secara aseptis dengan jarum ose pada media padat agar miring dan tabung media ditutup dengan kapas. Media tersebut diinkubasi selama 18 - 24 jam pada suhu 37 ${ }^{\circ} \mathrm{C}$ di dalam inkubator kemudian diletakkan dalam lemari pendingin.

\section{Pembuatan larutan Biakan Aktif}

Satu ose bakteri hasil peremajaan biakan murni $S$. aureus dan E. coli dibiakkan dalam $10 \mathrm{~mL}$ media cair (NB) steril dan dihomogenkan.

\section{Uji Aktivitas Antibakteri}

Ditambahkan 0,1 mL larutan biakan aktif bakteri $E$. coli dan $S$. aureus dalam cawan petri steril. Selanjutnya media agar padat $10 \mathrm{~mL}$ yang telah dipanaskan hingga mencair, didinginkan sampai suhu $40{ }^{\circ} \mathrm{C}$, dan dituang ke dalam cawan petri dan dihomogenkan. Media dibiarkan hingga memadat. Kertas cakram (diameter $5 \mathrm{~mm}$ ) diresapkan dalam ekstrak Chlorella $s p$. maing-masing konsentrasi $(5 \%, 10 \%, 15$ $\%, 20 \%$, dan $25 \%$ ) dan kontrol (kontrol positif: penisilin dan streptomisin), (kontrol negatif: pelarut dan MET). Kertas cakram tersebut diletakkan di atas permukaan media bakteri menggunakan pinset dan ditekan sedikit. Media bakteri yang sudah diberi bahan antibakteri diinkubasi pada suhu $37{ }^{\circ} \mathrm{C}$ selama $18-24$ jam dalam inkubator. Diameter zona hambat yang terbentuk diukur menggunakan penggaris untuk menentukan aktivitas antibakteri.

\section{Uji Golongan Senyawa Aktif}

Uji golongan senyawa aktif dilakukan dengan uji reagen pada golongan metabolit sekunder yaitu alkaloid, flavonoid, triterpenoid, steroid dan tanin.

\section{HASIL DAN PEMBAHASAN \\ Kultivasi Chlorella sp. dalam Medium Ekstrak Tauge (MET)}

Selama proses kultivasi, kultur Chlorella $s p$. juga mengalami perubahan warna. Hal ini menunjukkan bahwa kepadatan sel Chlorella sp. juga mengalami perubahan. Perubahan warna kultur Chlorella sp. selama kultivasi dapat dilihat pada Gambar 1.

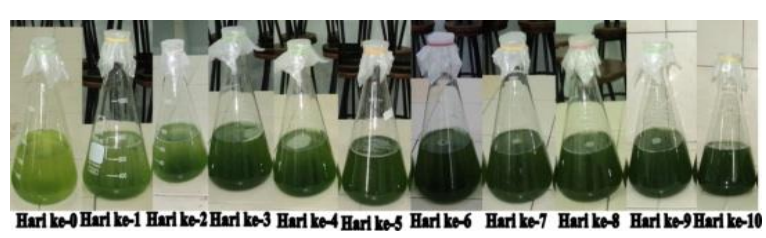

Gambar 1. Perubahan warna kultur Chlorella sp.

\section{Pemanenan Biomassa Chlorella sp.}

Pemanenan biomassa Chlorella sp. dilakukan pada fase stasioner yaitu hari ke10.

\section{Preparasi Sampel Biomassa Chlorella sp.}

Preparasi sampel biomassa mikroalga Chlorella sp. dilakukan dengan cara pengeringanginan selama \pm 12 jam menggunakan kipas angin. Pengeringan tidak dilakukan dengan menggunakan oven karena dikhawatirkan pengovenan dengan suhu tinggi dapat merusak senyawa yang terkandung di dalam biomassa Chlorella $s p$.

Preparasi sampel dengan cara pengeringanginan bertujuan untuk mengurangi kadar air pada sampel biomassa Chlorella sp. Hal ini dilakukan agar kerusakan akibat degradasi oleh mikroorganisme dapat diminimalkan serta mencegah tumbuhnya jamur sehingga dapat disimpan dalam waktu yang lama dan tidak merusak komposisi kimia di dalamnya. Rendemen pengeringanginan biomassa basah Chlorella sp. adalah 14,096 \% yaitu dari \pm 400 gram biomassa basah, setelah dikeringanginkan diperoleh \pm 55 gram biomassa kering yang telah berbentuk serbuk halus.

\section{Ekstraksi Biomassa Chlorella sp.}

Ekstraksi komponen aktif mikroalga Chlorella sp. dilakukan dengan metode maserasi dengan pelarut metanol. Ekstrak 
metanol yang diperoleh berupa ekstrak kental berwarna hijau tua. Hasil rendemen ekstrak metanol mikroalga Chlorella $s p$. pada fase stasioner adalah 7,001 \% .

\section{Uji Aktivitas Antibakteri Ekstrak Metanol Mikroalga Chlorella sp. terhadap E. Coli dan S. aureus}

Ekstrak metanol Chlorella sp. yang digunakan untuk uji aktivitas antibakteri adalah ekstrak dari fase stasioner. Pengujian ini dilakukan pada konsentrasi ekstrak yang berbeda yaitu $5 \%, 10 \%, 15 \%, 20 \%$, dan $25 \%$. Hasil uji aktivitas antibakteri ekstrak metanol Chlorella sp. masing-masing konsentrasi ditunjukkan pada Tabel 2.

Tabel 2. Hasil uji aktivitas antibakteri variasi konsentrasi

\begin{tabular}{ccc}
\hline Konsentrasi (\% b/v) & \multicolumn{2}{c}{$\begin{array}{c}\text { Zona Hambat } \\
(\mathbf{m m})\end{array}$} \\
\cline { 2 - 3 } & E. coli & $\begin{array}{c}\text { S. } \\
\text { aureus }\end{array}$ \\
\hline 5 & 1,0 & 2,2 \\
10 & 3,7 & 4,9 \\
15 & 6,9 & 3,0 \\
20 & 16,5 & 7,4 \\
25 & 12,1 & 13,1 \\
Kontrol Pelarut & - & - \\
Kontrol Media & - & - \\
Penisilin (5\%) & \multicolumn{2}{c}{30,0} \\
Sreptomisin (5\%) & 18,7 \\
\hline Keterangan : Kontrol negatif : Metanol dan MET. \\
Kontrol positif : Penisilin dan \\
Streptomisin.
\end{tabular}

Pemberian ekstrak metanol fase stasioner dengan konsentrasi yang berbeda juga menghasilkan zona hambat yang berbeda. Konsentrasi $20 \%$ menghasilkan zona hambat terbesar terhadap bakteri $E$. coli dan konsentrasi $25 \%$ menghasilkan zona hambat terbesar terhadap bakteri $S$. aureus. Hal ini menunjukkan bahwa konsentrasi yag memiliki aktivitas antibakteri terbaik adalah $20 \%$ terhadap bakteri $E$. coli dan $25 \%$ terhadap bakteri $S$. aureus.

Daya hambat ekstrak metanol Chlorella sp. dari fase stasioner pada konsentrasi terbaik terhadap bakteri E.coli dan bakteri $S$. aureus tergolong kuat (10-20 $\mathrm{mm}$ ) (Davis dan Stout, 1971 dalam Yudha, 2008).

\section{Uji Golongan Senyawa Aktif}

Uji golongan senyawa aktif dengan menggunakan reagen menunjukkan hasil positif pada golongan senyawa steroid dan golongan senyawa tanin. Hasil uji golongan senyawa aktif ekstrak metanol Chlorella $s p$. ditunjukkan pada Tabel 3.

Tabel 3. Hasil pengamatan uji kandungan golongan senyawa aktif ekstrak biomassa Chlorella sp.

\begin{tabular}{cc}
\hline Golongan & Hasil Uji pada Ekstrak \\
Senyawa & Metanol \\
\hline Alkaloid & - \\
Flavonoid & - \\
Tanin & + \\
Steroid & + \\
Triterpenoid & - \\
\hline Keterangan: tanda +: terkandung senyawa \\
tanda - : tidak terkandung senyawa \\
Steroid
\end{tabular}

Pengujian golongan senyawa steroid dilakukan dengan penambahan kloroform, asam asetat anhidrat dan $\mathrm{H}_{2} \mathrm{SO}_{4}$. pekat ke dalam larutan ekstrak. Penambahan $\mathrm{H}_{2} \mathrm{SO}_{4}$ dilakukan terakhir kali dan dialirkan melalui dinding tabung sedikit demi sedikit. Ekstrak metanol Chlorella sp. mengandung golongan senyawa steroid karena menunjukkan adanya perubahan warna dari hijau kekuningan menjadi hijau kebiruan setelah penambahan reagen tersebut.

Jika dalam larutan uji terdapat molekul air, maka asam asetat anhidrat akan berubah menjadi asam asetat sebelum reaksi berjalan dan turunan asetil tidak akan terbentuk. Triterpenoid memberikan reaksi terbentuknya cincin kecoklatan ketika senyawa ini ditetesi asam sulfat pekat melalui dindingnya, sedangkan steroid akan menghasilkan warna hijau kebiruan (Robinson, 1995). 
Steroid cenderung bersifat non polar. Golongan senyawa ini terdapat pada ekstrak metanol (sifat polar) dimungkinkan karena terikat dalam bentuk glikosidanya dimana unit steroid terikat pada suatu gula. Glikosida adalah kombinasi antara suatu gula dan suatu alkohol yang saling berikatan melalui ikatan glikosida.

\section{Tanin}

Pengujian tanin pada ekstrak metanol biomassa Chlorella sp. pada penelitian ini dilakukan dengan menggunakan 2 reagen, yaitu $\mathrm{FeCl}_{3}$ dan larutan gelatin. Hasil uji tanin menggunakan $\mathrm{FeCl}_{3}$ adalah negatif karena tidak menunjukkan adanya warna hijau kehitaman atau biru tua. Sedangkan hasil uji tanin menggunakan larutan gelatin adalah positif karena terbentuk endapan putih di dasar tabung pada ekstrak metanol biomassa Chlorella sp. Endapan putih terbentuk karena adanya ikatan hidrogen antara senyawaan tanin dengan gelatin.

Gelatin mengandung protein sehingga terbentuk senyawa komplek taninprotein, dikarenakan adanya ikatan hidrogen antara tanin dan protein pada gelatin sehingga dapat terbentuk endapan putih. Ikatan hidrogen ini terbentuk dari atom $\mathrm{H}$ yang berikatan dengan 2 atom yang memiliki keelektronegatifan yang tinggi seperti atom $\mathrm{N}, \mathrm{O}$ dan $\mathrm{F}$. Ikatan hidrogen yang terbentuk disebabkan oleh atom $\mathrm{H}$ yang terikat dengan 2 atom $\mathrm{O}$ ataupun yang terikat dengan atom $\mathrm{O}$ dan $\mathrm{N}$ dari struktur tanin dan gelatin

\section{KESIMPULAN}

1. Ekstrak metanol mikroalga Chlorella $s p$. dari fase stasioner mempunyai aktivitas antibakteri terhadap bakteri $E$. coli dan $S$. aureus. Zona hambat yang dihasilkan ekstrak metanol Chlorella sp. fase stasioner pada konsentrasi $5 \%, 10$ $\%, 15 \%, 20 \%$, dan $25 \%$ berturut-turut adalah $1,0 \mathrm{~mm}, 3,7 \mathrm{~mm}, 6,9 \mathrm{~mm}, 16,5$ $\mathrm{mm}$, dan $12,1 \mathrm{~mm}$ terhadap bakteri $E$. coli dan 2,2 mm, 4,9 mm, 3,0 mm, 7,4 $\mathrm{mm}$, dan $13,1 \mathrm{~mm}$ terhadap bakteri $S$. aureus. Konsentrasi terbaik adalah 20 $\%$ terhadap bakteri E. coli dan $25 \%$ terhadap bakteri $S$. aureus.

2. Golongan senyawa ekstrak metanol biomassa Chlorella sp. adalah steroid dan tanin.

\section{DAFTAR PUSTAKA}

Abedin, R. M. A. dan Taha, H. M. 2008. Antibacterial and Antifungal Activity of Cyanobacteria and Green Microalgae, Evaluation of Medium Components by PlackettBurman Design for Antimicrobial Activity of Spirulina platensis. Global Journal of Biotechnology and Biochemistry. Volume 3(1): 2231 .

Becker. 1994. Microalgae Biotechnology and Microbiology. London: Cambridge University Press.

Ben-Amotz; Fishler dan Schneller. 1987. Chemical Composition of Dietary Species of Marine Unicellular Algae and Rotifers with Emphasis on Fatty Acid. Marine Biology. Volume 95: 31-36.

Borowitzka, M. A. dan Lesley, J. B. 1988. Microalgae Biotechnology. London: Cambridge University Press.

Davis, W. W. dan Stout, T. R. 1971. Disc Plate Method of Microbiological Antibiotic Assay. Journal of Microbiology. 22(4): 659-665.

Prihantini, N. B., Putri, B. dan Yuniati, R. 2005. Pertumbuhan Chlorella sp. Dalam Medium Ekstrak Tauge (MET) Dengan Variasi $\mathrm{pH}$ Awal. Makara, Sains, Vol. 9(1) : 1 6.

Prihantini, N. B., Damayanti, D. dan Yuniati, R. 2007. Pengaruh Konsentrasi Medium Ekstrak Tauge (MET) terhadap Pertumbuhan Scenedesmus Isolat Subang. Makara, Sains, Vol. (11): 1 - 9.

Robinson, T. 1995. Kandungan Senyawa Organik Tumbuhan Tinggi. 
Terjemahan Prof. Dr. Kosasih Padmawinata. Bandung: ITB.

Rostini, I. 2007. Kultur Fitoplankton (Chlorella sp. dan Tetraselmis chuii) pada Skala Laboratorium. Skripsi Diterbitkan. Jatinangor: Universitas Padjajaran.

Sriwardani, T. 2000. Pemisahan Ekstrak Intraseluler dari Mikroalga Chlorella sp. dan Penentuan Konsentrasi Hambatan Minimum Terhadap Bakteri dan Kapang Patogen. Skripsi Diterbitkan. Bogor: Institut Pertanian Bogor.

Steenblock. 1996. Chlorella Makanan Sehat Alami. Jakarta: Gramedia Pustaka Utama.

Volk, W.A dan Wheeler, M.F. 1993. Mikrobiologi Dasar, Alih Bahasa :
Markham. Jakarta: PT. Glora Aksara Pratama.

Wulandari, A. P.; Naderia, F.; Pattalia, A. E. dan Permata, D. R. 2010. Identifikasi Mikroalgae di Sekitar Pantai Pangandaran dan Potensi Pertumbuhannya pada Formulasi Medium Ekstrak Tauge (MET). Prosiding Seminar Nasional Limnologi V Tahun 2010. Jatinangor: Jurusan Biologi FMIPA Universitas Padjadjaran. 535-542.

Yudha, A. P. 2008. Senyawa Antibakteri dari Mikroalga Dunaliella sp. pada Umur Panen yang Berbeda. Skripsi Diterbitkan. Bogor: Institut Pertanian Bogor. 